by Drosophila immigrans. Further investigation will target the scent produced by the flowers and the small projections on the sepals, to which the flies are attracted. The complex investigated diverged into four allopatric genetic lineages separated by the tall central mountain range in Costa Rica. Based on morphological and genetic differences we propose to recognize the different lineages as four separate species.

\title{
Morphological and phylogenetic characterization of the diversity of the genus Vanilla in the Colombian Pacific region
}

\author{
Francisco Hernando Molineros-Hurtado ${ }^{1,2,3^{*}}$, R. T. González-Mina ${ }^{1,3}$, J. T. Otero ${ }^{1,4,5}$ \\ \& N. S. Flanagan ${ }^{1,6}$
}

${ }^{1}$ Research Group in Orchids, Ecology, and Plant Systematics; ${ }^{2}$ Universidad Nacional de Colombia, Palmira, Colombia; ${ }^{3}$ Agronomy Program, Universidad del Pacífico, Buenaventura, Colombia; ${ }^{4}$ Biological Sciences Department, Universidad Nacional de Colombia, Palmira, Colombia; ${ }^{5}$ Environmental Studies Institute (IDEA Palmira), Universidad Nacional de Colombia, Palmira, Colombia; ${ }^{6}$ Biology Program, Pontificia Universidad Javeriana, Cali, Colombia; *Author for correspondence: franhermohur@yahoo.com

Vanilla extract, derived principally from the species Vanilla planifolia Andrews (Orchidaceae), is a highvalue crop for cultivation in lowland, humid tropical zones, offering an important economic opportunity for the "campesino" communities in these regions. The Neotropics represent the center of diversity for the clade that produces aromatic fruits, including $V$. planifolia. Eleven species of Vanilla are registered for Colombia. However, this genus is poorly documented in Colombia and across the region. Although the natural distribution of $V$. planifolia is controversial, the consensus is that it is native to Central America, and plants found in other regions are the result of anthropogenic activities. The taxonomy of the genus is difficult, with many herbarium accessions being sterile and infrequent flowering in natural populations. This study investigated the diversity of species of Vanilla present in the lowland humid tropical region along the Pacific coast of Colombia, combining morphological descriptors and DNA sequence data from the matK locus of the plastid genome and the ITS locus of the nuclear genome. Nine species were described. Three of these are new reports for Colombia: $V$. bicolor, $V$. helleri, and also a definitive identification of native $V$. planifolia. These results represent an important contribution to the knowledge of the Colombian flora, particularly of the Chocó Biodiversity Hotspot of the Colombian Pacific region. Additionally, this is an important first step in the development of sustainable vanilla production systems using native material. The promotion of effective conservation and sustainable management plans for these species is now a priority.

\section{Evolución de rasgos florales y vegetativos en el género Gavilea (Orchidaceae)}

\author{
María Isabel Mujica ${ }^{1 *}$ \& Fernanda Pérez ${ }^{1,2}$
}

${ }^{1}$ Instituto Milenio de Ecología y Biodiversidad, Facultad de Ciencias, Universidad de Chile, Las Palmeras 3425

Ñuñoa, Santiago, Chile; ${ }^{2}$ Center for Advanced Studies in Ecology and Biodiversity (CASEB), Departamento de Ecología, PontificiaUniversidad Católica de Chile, CP 6513677, Santiago, Chile

*Autor para correspondencia:mimujica@uc.cl

El género Gavilea Poepp. (Orchidaceae) es endémico del sur de Sudamérica. En Chile habitan 11 especies del género, que se distribuyen desde la zona central $\left(30^{\circ} \mathrm{S}\right)$ hasta el extremo sur del país $\left(55^{\circ} \mathrm{S}\right)$, incluyendo una especie endémica del Archipiélago de Juan Fernández. El objetivo de este trabajo fue aclarar la trayectoria evolutiva de los distintos rasgos florales y vegetativos de las especies del género 
Gavilea. Para esto, evaluamos la señal filogenética de diferentes rasgos de estas especies, analizando cuáles caracteres son más plásticos y cuáles se han mantenido más estables a lo largo de la filogenia de este taxón. Además, quisimos evaluar si dentro de los rasgos florales había algunos que estuvieran evolucionando en forma correlacionada. Evaluamos la señal filogenética y todos presentaron un índice $\mathrm{K}$ de Blomberg menor a 1 , no significativo $(\mathrm{P}>0,05)$ y un valor de lambda cercano a cero, sugierendo que los rasgos florales son evolutivamente plásticos. Sin embargo, al evaluar la correlación entre rasgos florales a través de contrastes independientes, se observó una correlación significativa entre varios de éstos, como el largo del sépalo dorsal con el largo del sépalo lateral, y el largo de las caudículas con el largo de los sépalos laterales, entre otros. Podemos concluir que los rasgos florales son evolutivamente plásticos en la filogenia de este género y que a su vez, algunos de éstos presentan una evolución correlacionada.

\title{
Atlas of orchids of the state of Santa Catarina
}

\author{
Marcelo Vieira Nascimento \\ Av. Dep. Diomicio Freitas 3160 - Casa 12, Bairro Carianos, Florianópolis/Santa Catarina, Brasil \\ mar@floripa.com.br
}

The state of Santa Catarina has a land area of $95,346,181 \mathrm{~km}^{2}$, totaling $1.19 \%$ of the total area of Brazil. The vegetation of the state consists of the following biomes: tropical Atlantic Forest coast, consisting of mangroves, dunes, beaches, and sandbanks; subtropical forest of Uruguay, with small vegetation; Araucaria forest, which is primarily composed of pine, cinnamon, cedar, yerba mate, and tree fern. In the plateau region we find the fields, the coldest region of the state. Despite representing only $1.19 \%$ of the total area of Brazil, the state is rich in the quantity and quality of orchids. Without doubt the most famous is Laelia purpurata, the official flower of the state of Santa Catarina and its capital Florianópolis. The Orchid Atlas of Santa Catarina is a unique initiative to disclose clearly and objectively the occurrence of the Orchidaceae there. The methodology for the Atlas is basically to 1) research the 14 herbaria in the state of

Santa Catarina, as well as São Paulo and Rio de Janeiro, trying to identify the vouchers from Santa Catarina; 2) review existing literature for Orchidaceae of Santa Catarina; 3) perform field work in all biomes of Santa Catarina over two years, trying to identify the species found and seeking confirmation of what has been deposited in the herbaria as well as other collections that perhaps have not yet been identified or registered for the state; 4) use GPS and GIS to prepare thematic maps of biomes and the location of the species found; and 5) identify, map, and photograph the biomes, listing for each one the genera and species occurring there as well as botanical descriptions and photos of the habitat, the plant as a whole, and the individual flower. So far we have found and identified 119 works, 465 orchid species, two subspecies, four varieties, and 16 endemic species of Santa Catarina. Monitoring of project results can be viewed at www.orquidarionsdodesterro.com.br.

\section{Orchidacae of Campeche Island, Florianópolis, Santa Catarina}

\author{
Marcelo Vieira Nascimento \\ Av. Dep. Diomicio Freitas 3160 - Casa 12, Bairro Carianos, Florianópolis/Santa Catarina, Brasil \\ mar@floripa.com.br
}

Campeche Island was declared a National Landscape and Archaeological Site through the Ministerial Decree No. 270, July 2000. It has an area of $4.0 \mathrm{~km}^{2}$. The existing plant diversity in the Island of
Campeche is provided by the different habitats found there: 1) sandy coastline, characterized by having a poor soil consisting mainly of fragments of quartz $(0.2$ to $10.0 \mathrm{~mm}$ in size), high permeability to water, and 